\title{
Mycoplasma cloacale, a New Species Isolated from a Turkey
}

\author{
JANET M. BRADBURY* AND MARGARET FORREST \\ Sub-Department of Avian Medicine, University of Liverpool, Leahurst, Neston, Wirral, L64 7TE, United Kingdom
}

\begin{abstract}
A mycoplasma designated strain $383^{\mathrm{T}}$ ( $\mathrm{T}=$ type strain) was isolated from the cloaca of a turkey poult. After examination of its morphological, physical, and cultural properties this organism was assigned to the class Mollicutes, order Mycoplasmatales. The base composition of its deoxyribonucleic acid was $26.0 \mathrm{~mol} \%$ guanine plus cytosine. Strain $383^{\mathrm{T}}$ was dependent on sterol for growth and was inhibited by digitonin. Since it gave no evidence of helical forms or of urea hydrolysis, it was assigned to the family Mycoplasmataceae, genus Mycoplasma. This organism hydrolyzed arginine and reduced triphenyltetrazolium chloride under anaerobic conditions, but other biochemical tests were negative. Strain $383^{\mathrm{T}}$ could not be identified as any of 83 currently accepted Mycoplasma species or serovars by growth inhibition, immunofluorescence, immunodiffusion, or metabolism inhibition tests. Thus, this mycoplasma appears to be a new species, for which we propose the name Mycoplasma cloacale; the type strain is strain 383 (= NCTC $10199=$ ATCC 35276).
\end{abstract}

A series of investigations in our laboratory (17; Forrest and Bradbury, Rev. Infect. Dis. 4:S272, 1982) identified the presence in domestic poultry of mycoplasmas which are distinct from the previously recognized avian species. Two such isolates from chickens have recently been established as new Mycoplasma species (5, 9).

In this paper we describe the characteristics of a third mycoplasma, strain $383^{\mathrm{T}}$ ( $\mathrm{T}=$ type strain), which was isolated from a turkey, by using the methods recommended by the International Committee on Systematic Bacteriology Subcommittee on the Taxonomy of Mollicutes (16) in order to establish whether an isolate represents a new mycoplasma species.

\section{MATERIALS AND METHODS}

Mycoplasma strains. The strains studied are shown in Table 1. Strain $383^{\mathrm{T}}$ was isolated from the cloaca of a turkey poult in 1975 . Reference strains of 74 currently accepted mycoplasma species or serovars were obtained from the sources described previously (5). The two new avian species, Mycoplasma lipofaciens (5) and Mycoplasma glycophilum (9), were also included, and additional species (and appropriate antisera) were obtained as follows: Mycoplasma cricetuli and Mycoplasma collis from A. Hill, Medical Research Council Experimental Embryology and Teratology Unit, Carshalton, Surrey, England; Mycoplasma californicum, Mycoplasma fastidiosum, and Mycoplasma mustelae from the Food and Agriculture Organization/World Health Organization Collaborating Centre for Animal Mycoplasmas, University of Aarhus, Aarhus, Denmark; and $\mathrm{Myco}^{-}$ plasma genitalium and Mycoplasma muris from J. Tully, Frederick Cancer Research Facility, Frederick, Md.

Media, cultivation, and purification methods. The media used to propagate most of these strains have been described previously (5). The additional species used in this study were grown in our routine medium (4). Mycoplasma faucium, Mycoplasma sualvi, and $M$. muris cultures were incubated anaerobically, and all other cultures were incubated in a candle jar. Attempts to grow $M$. fastidiosum and $M$. genitalium in a number of different medium formulations were unsuccessful. Strain $383^{\mathrm{T}}$ was filter-cloned three times, and this cloned culture and its antiserum was used in all tests

\footnotetext{
* Corresponding author.
}

unless otherwise indicated. A second clone was prepared from the original isolate by the same procedure.

Characterization studies. Strain $383^{\mathrm{T}}$ was examined by the methods used for $M$. lipofaciens (5). These included morphological studies on colonies, examination of cells by light and electron microscopy, and tests for the absence of reversion and for filterability. The deoxyribonucleic acid (DNA) base composition was estimated (25), and susceptibility to digitonin and sodium polyanethol sulfonate was determined $(8,10)$. Other biochemical tests performed with strain $383^{\mathrm{T}}$ included examination for a growth response to sterol (7) and for utilization of glucose, arginine, and urea (1). Tests for production of films and spots, phosphatase activity, tetrazolium reduction, serum digestion, and hydrolysis of esculin and arbutin were carried out as described previously (5). Strain $383^{\mathrm{T}}$ was also tested for hemadsorption of turkey and chicken erythrocytes (26).

Serological tests. Rabbits were hyperimmunized with $M y$ coplasma sp. strain $383^{\mathrm{T}}$ as described previously for $M$. lipofaciens (5). Growth inhibition (GI) tests, in which the agar well modification was used (2), were carried out with the rabbit antiserum and all of the reference strains of Mycoplasma except $M$. fastidiosum and $M$. genitalium strains. For some tests a modified medium was used (5). Reciprocal GI tests were performed by using all of the reference antisera and a strain $383^{\mathrm{T}}$ culture. Homologous controls were included for strain $383^{\mathrm{T}}$ and each reference culture except $M$. fastidiosum and $M$. genitalium.

Indirect fluorescent antibody (IFA) tests (24) were carried out with rabbit antiserum to strain $383^{\mathrm{T}}$ and the reference cultures, and both clones of strain $383^{\mathrm{T}}$ were tested against all of the reference antisera. Each culture was also tested with normal rabbit serum as a control, and homologous controls were also included for strain $383^{\mathrm{T}}$ and all of the reference mycoplasmas except $M$. fastidiosum and $M$. genitalium. Double immunodiffusion (DID) tests were performed by using strain $383^{\mathrm{T}}$ antigen (15) and 74 of the reference antisera (5), and metabolism inhibition tests were carried out for those strains which showed apparent cross-reactions with strain $383^{\mathrm{T}}$ in the other tests. The arginine color change method was used (22).

\section{RESULTS}

Morphological studies. Mycoplasma strain $383^{\mathrm{T}}$ grew well on mycoplasma agar in a candle jar or under anaerobic 
TABLE 1. Results of serological tests with Mycoplasma sp. strain $383^{\mathrm{T} a}$

\begin{tabular}{|c|c|c|c|c|c|c|c|c|}
\hline \multirow[b]{2}{*}{ Organism or serovar } & \multirow[b]{2}{*}{ Strain } & \multicolumn{2}{|c|}{ GI test ${ }^{b}$} & \multicolumn{3}{|c|}{ Indirect immunofluorescence ${ }^{c}$} & \multirow{2}{*}{$\begin{array}{c}\text { No. of } \\
\text { lines in } \\
\text { DID } \\
\text { test }^{d}\end{array}$} & \multirow[b]{2}{*}{$\begin{array}{l}\text { Metabolism } \\
\text { inhibition } \\
\text { test }^{e}\end{array}$} \\
\hline & & $\begin{array}{l}\text { Reference } \\
\text { antiserum }\end{array}$ & $\begin{array}{l}\text { Reference } \\
\text { culture }\end{array}$ & $\begin{array}{l}\text { Clone 1 } \\
\text { reference } \\
\text { antiserum }\end{array}$ & $\begin{array}{l}\text { Clone } 2 \\
\text { reference } \\
\text { antiserum }\end{array}$ & $\begin{array}{l}\text { Reference } \\
\text { culture }\end{array}$ & & \\
\hline M. cloacale & $383^{\mathrm{T}}$ & $7-8$ & & $3+$ & $3+$ & & 3 & $160 / 320$ \\
\hline M. bovis & Donetta ${ }^{\mathrm{T}}$ & 0 & 0 & 0 & 0 & $(1+)$ & 0 & $0 / 0$ \\
\hline M. bovoculi & $\mathrm{M} 165 / 69^{\mathrm{T}}$ & 0 & 0 & 0 & 0 & $(1+)$ & 0 & $0 / 0$ \\
\hline M. collis & $58 \mathrm{~B}^{\mathrm{T}}$ & 0 & 0 & 0 & 0 & $(1+)$ & $\mathrm{ND}^{f}$ & ND \\
\hline M. columbinasale & $694^{\mathrm{T}}$ & 0 & 0 & 0 & 0 & 0 & (1) & $10 / 0$ \\
\hline M. columbinum & $\mathrm{MMP1}^{\mathrm{T}}$ & 0 & 0 & 0 & 0 & 0 & (1) & $0 / 0$ \\
\hline M. dispar & $462 / 2^{T}$ & 0 & 0 & 0 & 0 & 0 & $1,(1)$ & $0 / 0$ \\
\hline M. flocculare & $\mathrm{Ms} 42^{\mathrm{T}}$ & 0 & 0 & 0 & 0 & 0 & (1) & $0 / 0$ \\
\hline M. lipofaciens & $\mathrm{R} 171^{\mathrm{T}}$ & 0 & 2 & 0 & 0 & 0 & 1 & $0 / 0$ \\
\hline M. molare & $\mathrm{H} 542^{\mathrm{T}}$ & 0 & 0 & 0 & 0 & $(1+)$ & 0 & $0 / 0$ \\
\hline M. neurolyticum & $A^{T}$ & 0 & (2) & 0 & 0 & 0 & 0 & $0 / 0$ \\
\hline M. pneumoniae & $\mathrm{FH}^{\mathrm{T}}$ & 0 & 0 & 0 & 0 & 0 & 1 & $0 / 0$ \\
\hline M. salivarium & $\mathrm{PG}^{\mathrm{T}}{ }^{\mathrm{T}}$ & 0 & 0 & 0 & 0 & 0 & 1 & $0 / 0$ \\
\hline M. sualvi & Mayfield $\mathrm{B}^{\mathrm{T}}$ & 0 & 5 & 0 & 0 & 0 & 0 & $0 / 0$ \\
\hline Ovine serovar 7 & A1343 & 0 & 0 & 0 & 0 & $(1+)$ & 0 & $0 / 0$ \\
\hline
\end{tabular}

${ }^{a}$ Results of tests were negative in comparisons with $M$. agalactiae $\mathrm{PG}^{\mathrm{T}}, M$. alkalescens $\mathrm{D} 12^{\mathrm{T}}, M$. alvi Ilsley ${ }^{\mathrm{T}}, M$. anatis $1340^{\mathrm{T}}, M$. arginini $\mathrm{G} 230^{\mathrm{T}}, M$. arthritidis PG6 ${ }^{\mathrm{T}}, M$. bovigenitalium PG11 ${ }^{\mathrm{T}}, M$. bovirhinis $\mathrm{PG}_{3} \mathrm{~T}^{\mathrm{T}}, M$. buccale $\mathrm{CH} 20247^{\mathrm{T}}, M$. californicum ST-6, $M$. canadense $275 \mathrm{C}^{\mathrm{T}}$, $M$. canis $\mathrm{PG} 14^{\mathrm{T}}, M$, capricolum California $\mathrm{Kid}^{\mathrm{T}}, M$. caviae $\mathrm{G} 122^{\mathrm{T}}, M$. citelli $\mathrm{RG}-2 \mathrm{C}^{\mathrm{T}}, M$. columborale MMP4 ${ }^{\mathrm{T}}, M$. conjunctivae $\mathrm{HRC}^{\mathrm{T}} \mathrm{C1}^{\mathrm{T}}, M$. cricetuli $\mathrm{CH} \mathrm{T}^{\mathrm{T}}, M$. cynos $\mathrm{H} 831^{\mathrm{T}}, M$. edwardii $\mathrm{PG} 24^{\mathrm{T}}, M$. equigenitalium $\mathrm{T} 37^{\mathrm{T}}, M$. equirhinis $\mathrm{M} 432 / 72^{\mathrm{T}}, M$. fastidiosum $4822^{\mathrm{T}}, M$. faucium $\mathrm{DC} 333^{\mathrm{T}}, M$. feliminutum Ben ${ }^{\mathrm{T}}, M$. felis $\mathrm{CO} \mathrm{T}^{\mathrm{T}}, M$. fermentans $\mathrm{PG} 18^{\mathrm{T}}, M$. gallinaceum $\mathrm{DD}^{\mathrm{T}}, M$. gallinarum $\mathrm{PG} 16^{\mathrm{T}}, M$. gallisepticum $\mathrm{PG} 31^{\mathrm{T}}, M$. gallopavonis WR1 ${ }^{\mathrm{T}}, M$. gateae $^{\mathrm{C}} \mathrm{CS}^{\mathrm{T}}, M$. genitalium $\mathrm{G}-37^{\mathrm{T}}, M$. glycophilum $486^{\mathrm{T}}, M$. hominis $\mathrm{PG} 21^{\mathrm{T}}, M$. hyopneumoniae $\mathrm{J}^{\mathrm{T}}, M$. hyorhinis $\mathrm{BTS}-7^{\mathrm{T}}, M$. hyosynoviae $\mathrm{S} 16^{\mathrm{T}}, M$. iners $\mathrm{PG} 30^{\mathrm{T}}, M$. iowae $695^{\mathrm{T}}, M$. lipophilum MaBy ${ }^{\mathrm{T}}$, M. maculosum PG15 $5^{\mathrm{T}}, M$. meleagridis $17529^{\mathrm{T}}, M$. moatsii $\mathrm{MK}^{2} \mathrm{~S}^{\mathrm{T}}, M$. muris RIII4 ${ }^{\mathrm{T}}$ (antiserum prepared with strain RIII8), $M$. mustelae MX9 ${ }^{\mathrm{T}}, M$. mycoides

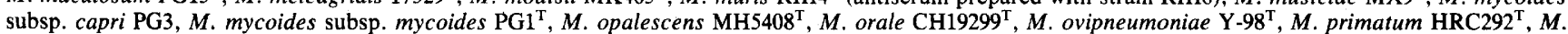
pullorum $\mathrm{CKK}^{\mathrm{T}}, M$. pulmonis $\mathrm{PG} 34^{\mathrm{T}}, M$. putrefaciens $\mathrm{KS}-1^{\mathrm{T}}, M$. spumans $\mathrm{PG} 13^{\mathrm{T}}, M$. subdolum $\mathrm{TB}^{\mathrm{T}}, M$. synoviae $\mathrm{WVU}$. $1853^{\mathrm{T}}, M$. verecundum $107^{\mathrm{T}}$, avian serovar J strain DJA, avian serovar K strain DK-CPA, avian serovar N strain FMN, avian serovar Q strain L3-10B, avian serovar R strain DRA-O, bovine group 7 strain PG50, bovine group L strain B144P, ovine group 5 strain goat 145 , ovine group 6 strain goat 189 , and ovine group 11 strain $2 \mathrm{D}$.

${ }^{b} 0$, Negative result. The numbers indicate the sizes of the inhibition zones (in millimeters). The parentheses indicate that inhibition was only partial and breakthrough occurred.

${ }^{c} 0$, Negative result; $1+$, weak fluorescence; $3+$, strong fluorescence. The parentheses indicate that the culture gave the same reaction with normal rabbit serum.

${ }^{d}$ The parentheses indicate precipitation lines which were not common with strain $383^{\mathrm{T}}$.

'Expressed as the reciprocal of the serum dilution.

${ }^{f} \mathrm{ND}$, Not done.

conditions. It produced typical fried egg colonies with welldefined and lightly pigmented central zones. Giemsa-stained films showed minute coccoid elements, and phase-contrast and dark-field microscopy revealed single cells, pairs, and clumps of organisms. Filaments and ring forms were not seen. Electron microscopy of thin sections demonstrated the absence of a cell wall and the presence of a triple-layer membrane (Fig. 1). The cells were mainly spherical or elliptical, and there were areas of increased cytoplasmic density adjacent to the cell membrane (Fig. 2). The average diameter of the cells was $515 \mathrm{~nm}$ (range, 351 to $702 \mathrm{~nm}$ ). Smaller elementary bodies (100 to $200 \mathrm{~nm}$ ) were also seen but were not included in the size estimations.

Reversion studies. There was no evidence of reversion to bacteria after 10 passages in broth or agar without inhibiting substrates.

Filtration studies. A culture of strain $383^{\mathrm{T}}$ diluted $1: 10$ in phosphate-buffered saline supplemented with $0.2 \%$ gelatin contained $6.1 \times 10^{6}$ colony-forming units per $\mathrm{ml}$, and filtrates after passage through 450 - and 220 -nm filters contained $2.6 \times 10^{6}$ and $4.5 \times 10^{2}$ colony-forming units per ml, respectively.

DNA base composition. The guanine-plus-cytosine content of DNA extracted from strain $383^{\mathrm{T}}$ was estimated to be 26.0 mol\% by cesium chloride density gradient analysis.

Biochemical tests. Mycoplasma strain $383^{\mathrm{T}}$ was susceptible to $1.5 \%$ (wt/vol) digitonin, giving an inhibition zone of $4 \mathrm{~mm}$, but it was not inhibited by 5 or $20 \%$ (wt/vol) sodium polyanethol sulfonate. The growth response to sterol was clearly demonstrated on agar medium. There was no growth on basal medium without supplements (7) and only occasional sparse growth in the presence of added bovine albumin and palmitic acid. In contrast, there was good growth in the presence of cholesterol, even at low concentrations $(0.2$ to 5 $\mu \mathrm{g} / \mathrm{ml})$. The results of other biochemical tests are given below.

Serological tests. Rabbit antiserum prepared against strain $383^{\mathrm{T}}$ gave an inhibition zone of 7 to $8 \mathrm{~mm}$ in GI tests and an IFA reciprocal titer of 640 with the homologous culture. In homologous DID tests with strain $383^{\mathrm{T}}$ three precipitation lines were produced, and metabolism inhibition tests gave reciprocal titers between 160 and 320 . The serological tests with the reference reagents did not give any reactions that were comparable to the homologous reactions (Table 1). In GI tests three reference cultures, $M$. lipofaciens, $M$. neurolyticum, and $M$. sualvi, were inhibited by antiserum to strain $383^{\mathrm{T}}$. In IFA tests five reference cultures gave weak fluorescence with this antiserum; these cultures were $M$. bovis, $M$. bovoculi, $M$. collis, M. molare, and ovine serovar 7 cultures, but they gave the same weak fluorescence with the normal rabbit serum control.

There were no positive results in GI or IFA tests with the reference antisera and a strain $383^{\mathrm{T}}$ culture. In DID tests, seven reference antisera gave precipitation lines with strain $383^{\mathrm{T}}$ antigen, but three of these antisera $(M$. columbinasale, $M$. columbinum, and $M$. flocculare) produced a single precipitation line which showed no identity with strain $383^{\mathrm{T}}$. The other four ( $M$. dispar, $M$. lipofaciens, $M$. pneumoniae, and $M$. salivarium) each gave a line that was common to one of the lines given by strain $383^{\mathrm{T}}$ and its antiserum, and $M$. 


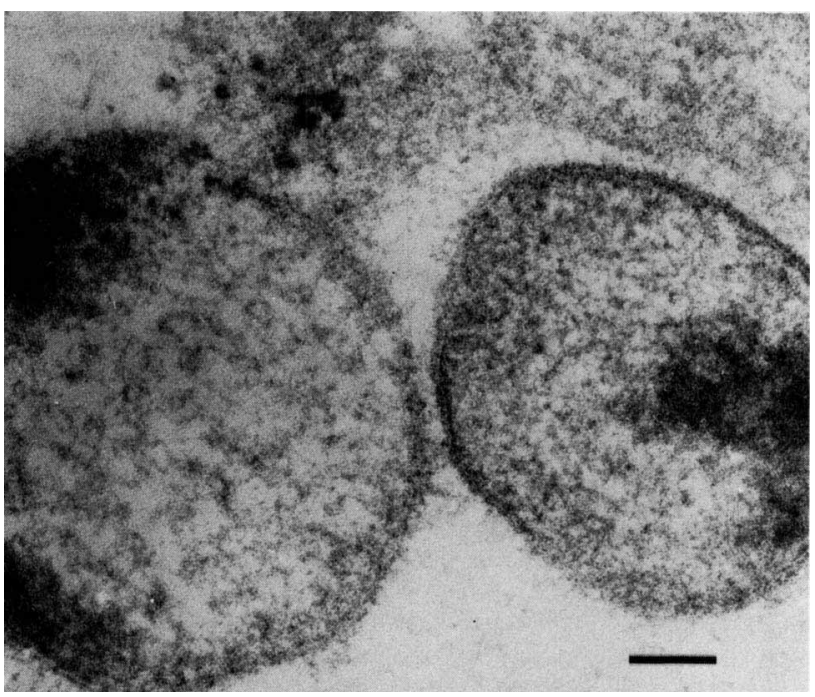

FIG. 1. Thin section of strain $383^{\mathrm{T}}$ cells. Bar $=100 \mathrm{~nm}$.

dispar antiserum also gave a second line that showed no identity.

Positive results were not observed in metabolism inhibition tests, except in one test with $M$. columbinasale which gave a reciprocal titer of 10 ; this result was not confirmed by the duplicate test.

\section{DISCUSSION}

Strain $383^{\mathrm{T}}$ had colonial and cellular morphology and cultural characteristics that were consistent with membership in the class Mollicutes as defined by The International Committee on Systematic Bacteriology Subcommittee on the Taxonomy of Mollicutes (16). Electron microscope examination of thin sections confirmed the lack of a cell wall and the presence of a triple-layer membrane, and estimates of cell size were similar to the observations of other workers $(6,21)$. The number of cells which passed through the 220$\mathrm{nm}$ pore filter was greater than expected from the cell size estimates, but the preparative techniques for electron microscopy may have altered the morphology of the cells (3, $12,20,21)$. Also, it is possible that the smaller particles $(100$ to $200 \mathrm{~nm}$ ), which were not included in the size estimations, were viable, although these elementary bodies are not generally thought to represent viable organisms $(21,23)$. Another possible explanation for the discrepancy could be that cells of strain $383^{\mathrm{T}}$ are susceptible to being squeezed through small pores (19).

The DNA base composition of strain $383^{\mathrm{T}}$ fell within the range reported for the Mollicutes (22.8 to $41.0 \mathrm{~mol} \%$ ) (18), and there was no evidence of reversion to bacterial forms.

The sterol requirement of strain $383^{\mathrm{T}}$ was clearly demonstrated by its growth response to cholesterol and its susceptibility to digitonin, and this distinguishes it from members of the family Acholeplasmataceae. The organism was resistant to sodium polyanethol sulfonate, but resistance has been reported previously in certain Mycoplasma species and seems to be a more common occurrence in arginine-hydrolyzing species $(8,10,13,14)$.

Strain $383^{\mathrm{T}}$ appears to be a facultative anaerobe, and since our investigations revealed no evidence of helical forms or motile filaments, we concluded that strain $383^{\mathrm{T}}$ does not belong to the genus Anaeroplasma or to the family Spiroplasmataceae. Since tests for urea hydrolysis were negative, the genus Ureaplasma can also be excluded, and we propose that the organism be assigned to the family Mycoplasmataceae, genus Mycoplasma.

There was no evidence to suggest that strain $383^{\mathrm{T}}$ is identical to any previously recognized Mycoplasma species. In the serological tests 83 such species were represented; only a few reactions were observed, and these reactions were not comparable with the homologous reactions. The growth inhibitory zone of $5 \mathrm{~mm}$ observed with a $M$. sualvi culture was judged to be nonspecific because we have observed similar inhibition of this culture with rabbit antisera prepared in our laboratory to $M$. lipofaciens (5) and $M$. glycophilum (9). A $M$. lipofaciens culture was also inhibited by strain $383^{\mathrm{T}}$ antiserum, but this mycoplasma is inhibited by some normal rabbit sera (5). The zone observed with a $M$. neurolyticum culture contained many breakthrough colonies, and other tests did not confirm a serological relationship with strain $383^{\mathrm{T}}$.

The five species which reacted in the IFA tests were different from those showing growth inhibition, and since all five species gave the same degree of fluorescence with normal rabbit serum, these reactions were considered to be nonspecific. The other serological tests gave no evidence of significant antigenic relationships between strain $383^{\mathrm{T}}$ and the reference antisera. In DID tests strain $383^{\mathrm{T}}$ antigen showed evidence of a common antigen with four reference species; however, this test is not as species specific as the other serological tests (11).

Strain $383^{\mathrm{T}}$ utilized arginine but not glucose and as such is biochemically similar to five previously described avian Mycoplasma species ( $M$. columbinasale, $M$. columbinum, $M$. gallinarum, $M$. iners, and $M$. meleagridis). The guanineplus-cytosine content of the DNA of strain $383^{\mathrm{T}}$ is close to that of $M$. gallinarum, $M$. iners, and $M$. meleagridis, but this does not imply identity (18); there is no evidence of a serological relationship between strain $383^{\mathrm{T}}$ and these species.

Therefore, we believe that strain $383^{\mathrm{T}}$ is a new Mycoplasma species, for which we propose the name Mycoplasma cloacale (clo a ca' le. L.n. cloaca cloaca; M.L. neut. adj. cloacale of the cloaca). Preliminary pathogenicity studies indicated that this mycoplasma could cause mortality in turkey embryos, but the results of repeated experiments

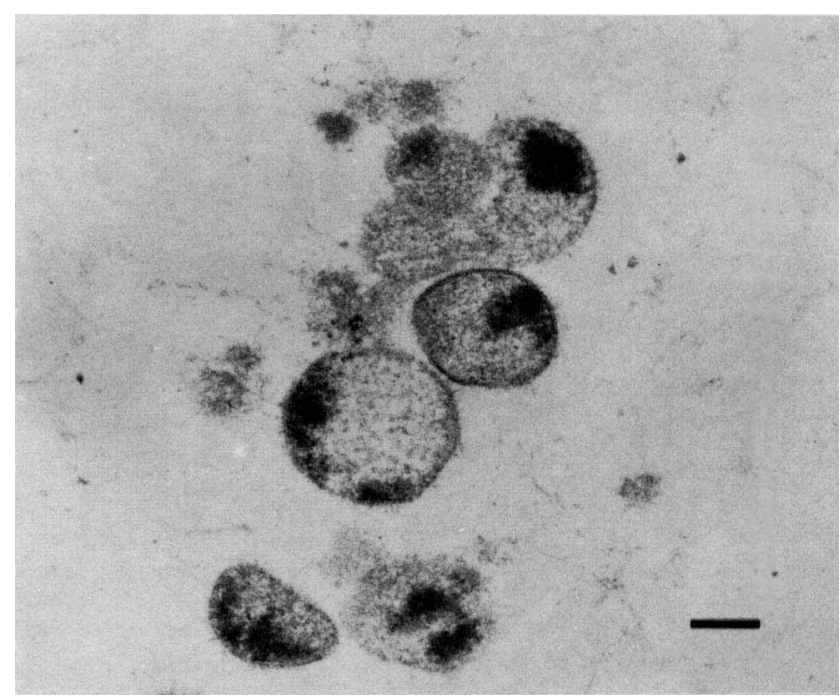

FIG. 2. Thin section of strain $383^{\mathrm{T}}$ cells. Bar $=250 \mathrm{~nm}$. 
were not consistent. So far this strain has been isolated from only one other turkey and has not been found in chickens; however, it has been isolated from the cloacae of a number of wild and exotic birds.

Mycoplasma cloacale sp. nov. Thin sections show mainly spherical and elliptical particles with a triple-layer cell membrane and no cell wall.

The average diameter of cells is $515 \mathrm{~nm}$. Cells pass through filters with $450-\mathrm{nm}$ pores, and a proportion pass through filters with 220 -nm pores.

Typical fried egg colonies are produced.

Cultures are resistant to penicillin and thallium acetate, and no reversion to cell wall forms occurs in the absence of these compounds.

Cultures show a positive growth response to cholesterol, and growth is inhibited by digitonin but not by sodium polyanethol sulfonate.

Arginine is utilized, but glucose and urea are not.

Triphenyl tetrazolium chloride is reduced anaerobically but not aerobically.

Cultures produce no phosphatase or film and spot activity, no serum digestion, and no hydrolysis of esculin or arbutin. There is no adsorption of chicken or turkey erythrocytes.

The species is serologically distinct from other Mycoplasma species.

The type strain was isolated from the cloaca of a turkey poult.

The pathogenicity is not known.

The guanine-plus-cytosine content of the DNA is 26 mol\%.

Type strain: strain 383 (= NCTC 10199 = ATCC 35276).

\section{ACKNOWLEDGMENTS}

We thank Janet D. McCarthy and Alison Williams for technical assistance and M. J. Daniels (John Innes Institute, Norwich, United Kingdom) for carrying out the DNA base composition estimations. We also thank A. Hill, E. A. Freundt, and J. Tully for providing cultures and antisera.

We thank the Overseas Development Administration for financial support.

\section{LITERATURE CITED}

1. Aluotto, B. B., R. G. Wittler, C. O. Williams, and J. E. Faber. 1970. Standardized bacteriologic techniques for the characterization of Mycoplasma species. Int. J. Syst. Bacteriol. 20:3558.

2. Black, F. T. 1973. Modifications of the growth inhibition test and its application to human T-mycoplasmas. Appl. Microbiol. 25:528-533.

3. Boatman, E. S. 1979. Morphology and ultrastructure of the Mycoplasmatales, p. 63-102. In M. F. Barile and S. Razin (ed.), The mycoplasmas, vol. 1. Cell biology. Academic Press, Inc., New York.

4. Bradbury, J. M. 1977. Rapid biochemical tests for characterization of the Mycoplasmatales. J. Clin. Microbiol. 5:531-534.

5. Bradbury, J. M., M. Forrest, and A. Williams. 1983. Mycoplasma lipofaciens, a new species of avian origin. Int. J. Syst.
Bacteriol. 33:329-335.

6. Domermuth, C. H., M. H. Nielsen, E. A. Freundt, and A. BirchAndersen. 1964. Ultrastructure of Mycoplasma species. J. Bacteriol. 88:727-744.

7. Edward, D. G. ff. 1971 . Determination of sterol requirement for Mycoplasmatales. J. Gen. Microbiol. 69:205-210.

8. Ernø, H., and L. Stipkovits. 1973. Bovine mycoplasmas: cultural and biochemical studies I. Acta Vet. Scand. 14:436-449.

9. Forrest, M., and J. M. Bradbury. 1984. Mycoplasma glycophilum, a new species of avian origin. J. Gen. Microbiol. 130:597603.

10. Freundt, E. A., B. E. Andrews, H. Ernø, M. Kunze, and F. T. Black. 1973. The sensitivity of Mycoplasmatales to sodiumpolyanetholsulfonate and digitonin. Zentralbl. Bakteriol. Parasitenkd. Infektionskr. Hyg. Abt. 1 Orig. Reihe A 255:104-112.

11. Freundt, E. A., H. Ernø, and R. M. Lemcke. 1979. Identification of mycoplasmas, p. 377-434. In T. Bergan and J. R. Norris (ed.), Methods in microbiology, vol. 13. Academic Press, Inc., London.

12. Furness, G., M. DeMaggio, and J. Whitescarver. 1975. Morphological changes induced during fixation of Mycoplasma mycoides for electron microscopy. Tex. Rep., Biol. Med. 33:415422.

13. Gourlay, R. N., S. G. Wyld, and R. H. Leach. 1977. Mycoplasma alvi, a new species from bovine intestinal and urogenital tracts. Int. J. Syst. Bacteriol. 27:86-96.

14. Gourlay, R. N., S. G. Wyld, and R. H. Leach. 1978. Mycoplasma sualvi, a new species from the intestinal and urogenital tract of pigs. Int. J. Syst. Bacteriol. 28:289-292.

15. Hollingdale, M. R., and R. M. Lemcke. 1969. The antigens of Mycoplasma hominis. J. Hyg. 67:585-602.

16. International Committee on Systematic Bacteriology Subcommittee on the Taxonomy of Mollicutes. 1979. Proposal of minimal standards for descriptions of new species of the class Mollicutes. Int. J. Syst. Bacteriol. 29:172-180.

17. Jordan, F. T. W., and M. Amin. 1980. A survey of mycoplasma infections in domestic poultry. Res. Vet. Sci. 28:96-100.

18. Kelton, W. H., and M. Mandel. 1969. Deoxyribonucleic acid base compositions of mycoplasma strains of avian origin. J. Gen. Microbiol. 56:131-135.

19. Lemcke, R. M. 1971. Sizing small organisms. Nature (London) 229:492-493.

20. Lemcke, R. M. 1972. Osmolar concentration and fixation of mycoplasmas. J. Bacteriol. 110:1154-1162.

21. Maniloff, J., and H. J. Morowitz. 1972. Cell biology of the mycoplasmas. Bacteriol. Rev. 36:263-290.

22. Purcell, R. H., D. Taylor-Robinson, D. C. Wong, and R. M. Chanock. 1966. A color test for the measurement of antibody to the non-acid-forming human mycoplasma species. Am. J. Epidemiol. 84:51-66.

23. Robertson, J., M. Gomersall, and P. Gill. 1975. Mycoplasma hominis: growth, reproduction, and isolation of small viable cells. J. Bacteriol. 124:1007-1018.

24. Rosendal, S., and F. T. Black. 1972. Direct and indirect immunofluorescence of unfixed and fixed mycoplasma colonies. Acta Pathol. Microbiol. Scand. Sect. B 80:615-622.

25. Schildkraut, C. L., J. Marmur, and P. Doty. 1962. Determination of the base composition of deoxyribonucleic acid from its buoyant density in CsCl. J. Mol. Biol. 4:430-443.

26. Sobeslavsky, O., B. Prescott, and R. M. Chanock. 1968. Adsorption of Mycoplasma pneumoniae to neuraminic acid receptors of various cells and possible role in virulence. J. Bacteriol. 96:695-705. 